\title{
Pen Gram Protein
}

National Cancer Institute

\section{Source}

National Cancer Institute. Pen Gram Protein. NCI Thesaurus. Code C78786.

A measure of the amount (in grams) of amino acids prescribed for parenteral and enteral therapy. 